\title{
PHOTOSYNTHESIS, DRY MATTER PARTITIONING AND YIELD VARIATION IN SESAME GENOTYPES
}

\author{
M. Akter ${ }^{1}$, Q. A. Khaliq ${ }^{1}$, M. R. Islam ${ }^{1}$ and J. U. Ahmed ${ }^{2}$ \\ ${ }^{1}$ Department of Agronomy, ${ }^{2}$ Department of Crop Botany \\ Bangabandhu Sheikh Mujibur Rahman AgriculturalUniversity,Gazipur-1706 \\ Corrosponding author: aktermunny026@gmai.com
}

Key words: Photosynthetic rate, Light interception, Dry matter partitioning, Seed and oil yield, Sesame

\begin{abstract}
An experiment was conducted at the research field of Bangabandhu Sheikh Mujibur Rahman Agricultural University, Gazipur-1706 from March to June 2014 to evaluate growth and yield performance of sesame genotypes. Five sesame genotypes i.e. DB-6992, BD-6995, BD-7001, BD-7011 and Hathazari-4 were used in the study. The genotypes significantly differed in photosynthetic rate, dry matter partitioning and seed yield. The earliest genotype was Hathazari-4 and the latest was BD-7011. The highest stem dry weight, leaf dry weight, capsule dry weight, leaf area index, light interception, photosynthetic rate were recorded in genotype Hathazari-4. The number of capsules plant ${ }^{-1}$ and the number of seeds capsule ${ }^{-1}$ were also highest in the genotype Hathazari-4, while the lowest was being noticed in the genotype BD7001. Weight of 1000-seed was the maximum in genotype BD-6992 and the minimum in the genotype BD- 7011. The highest seed yield $\left(3.52\right.$ tha $\left.^{-1}\right)$ was recorded in the genotype Hathazari-4 and the lowest in the genotypes BD-6992 followed by BD-7001. The highest oil content $(41.39 \%)$ was recorded in the genotype BD-6992 and the lowest (39.72\%) in the genotype Hathazari-4 but the highest oil yield $\left(1.53 \mathrm{t} \mathrm{ha}^{-1}\right)$ was recorded in the genotype Hathazari-4. It may be concluded that the sesame genotype Hathazari-4 may be cultivated for higher seed yield and oil production.
\end{abstract}

\section{Introduction}

Sesame (Sesamum indicum L.), known as "Til" in Bangladesh, belongs to the family Pedaliaceae. Average sesame yield in Bangladesh is about ha ${ }^{-1}$. Currently, about 33275 hectares of land are under sesame cultivation and annual production is about $29,965 \mathrm{~m}$ tons (BBS, 2012). In Bangladesh it is grown in almost all districts but grows well in greater Khulna, Faridpur, Pabna, Barisal, Rajshahi, Jessore, Comilla, Dhaka, Rangpur, Sylhet, and Mymensingh districts. Sesame is cultivated in both kharif I and kharif II seasons, but twothird of sesame is produced in kharif I season. Sesame needs a constant high temperature ranging from 26 to $30^{\circ} \mathrm{C}$ for optimum growth. Sesame requires a minimum of $300-400 \mathrm{~mm}$ rainfall (Carlsson et al., 2008).

Sesame seeds contain $38-54 \%$ oil, $18-20 \%$ protein, 567 kcal energy, $26.04 \mathrm{~g}$ carbohydrates, $5 \mathrm{~g}$ water, $131 \mathrm{mg}$ calcium, $7.78 \mathrm{mg}$ iron etc. in $100 \mathrm{~g}$ of seed (Banglapedia, 2012). The oil is utilized for the manufacture of soap, insecticide and paint (Vaughan, 2000). The seed is used in making various food items like bread, cakes, pastry, khaja, biscuits, etc. Sesame produces no seed or a very low seed yield if it is grown under unfavorable environmental conditions (Pham et al., 2010). Another major cause of poor yield of sesame is low yielding cultivars. The yield ability of sesame crop is determined by many yield components, all of which are substantially influenced by environmental conditions and agronomic practices 
Akter et al.

(Caliscan, 2004). It is important to understand yield potential and the improvement in partitioning of photosynthetic products. Photosynthesis is considered as the most important physiological process that governs the growth and yield of crops. Photosynthesis process of sesame varied over a wide range of genetical and environmental conditions (Ojima et al., 1969). Information relating to photosynthetic rate, dry matter partitioning and yield variation in sesame is very limited. Therefore, the present study was undertaken to identify the best sesame genotypes based on photosynthetic rate, dry matter partitioning and yield.

\section{Materials and Methods}

The experiment was conducted at the Field Research Site of the Bangabandhu Sheikh Mujibur Rahman Agricultural University, Gazipur-1706 from March, 2014 to June, 2014. It is located in Madhupur Tract under Agro Ecological Zone (AEZ) 28. The soil of the experimental site is silty clay in topsoil and silty clay loam in subsoil. The site is situated in the sub-tropical region characterized by heavy rainfall during monsoon at the months from March to June and scanty rainfall in the rest of the months of the year. The five selected sesame genotypes were BD-6992, BD-6995, BD-7001, BD-7011 and Hathazari-4. The land preparation was done well by repeated ploughing and cross-ploughing with a tractor drawn disc plough and then harrowed. The experiment was laid out in a Randomized Complete Block Design (RCBD) with four replications. The unit plot size was $1.2 \mathrm{~m} \times 1.5 \mathrm{~m}$. All the treatment plots were fertilized with 43.4, 23, 40.5, 18, 2 and $0.8 \mathrm{~kg}$ of N P K S Zn and B ha ${ }^{-1}$, respectively as urea, triple super phosphate, muriate of potash, gypsum and borax (BARC, 2012). Total amount of triple super phosphate, muriate of potash and gypsum fertilizers were applied plot wise during final land preparation before sowing. $2 / 3(43.4 \mathrm{~kg})$ nitrogen as basal and all the fertilizers were applied by broadcasting and mixed thoroughly with soil. One- third $(21.6 \mathrm{~kg}) \mathrm{N}$ was top dressed at 20 days after emergence (DAE). Sesame seeds at the rate of $3.5 \mathrm{~kg} \mathrm{ha}^{-1}$ were sown in line by hand on $3 \mathrm{March}, 2014$. Sesame took $3-4$ days to emergence. Pre-sowing irrigation was given to ensure the maximum germination percentage. Subsequent irrigation was also provided to avoid moisture stress. Three times weeding and mulching, two times insecticides spraying were performed to keep the field free from pests. Data on agronomic traits regarding on phenological and morphological characters of sesame including days to first flowering, days to maturity, plant height, number of leaves per plant, leaf area index, dry weight of leaves per plant, dry weight of stem per plant were recorded. Data on yield and yield contributing characters were measured from randomly selected plants. Leaf area index (LAl) and Light interception (LI) were measured by using standard formulae. The formulae used for different parametrs are given below.

Leaf area index $(\mathrm{LAl})=\frac{\text { Leaf area }}{\text { Ground area occupiedby plant }}$

Light transmission ratio $($ LTR $)=\frac{1}{10} \times 100$

Where, $I_{0}=$ Photosynthetically active radiation on the top of the canopy, $\mathrm{I}=$ Photosynthetically active radiation on the base of the canopy.

Light interception $(\mathrm{LI} \%)=100(\%)-$ LTR (\%)

Dry weight of leaves per plant $=\frac{\text { Leaf dry weight }(\mathrm{g})}{\text { Number of plants }}$ 
Photosynthesis, Dry Matter Partitioning and Yield Variation in Sesame Genotypes

Dry weight of stem per plant $=\frac{\text { Leaf dry weight }(\mathrm{g})}{\text { Number of plants }}$

Oil content (percent) $=\frac{\text { Weight of oil extracted }(\mathrm{g})}{\text { Weight of samples }} \times 100$

Oil yield was determined as follows:

Oil yield $\left(\mathrm{t} \mathrm{ha}^{-1}\right)=\frac{\text { Grain yield }}{\text { Oil content }(\%)}$

The collected data were analyzed statistically and the mean differences were adjusted by Least Significance Difference (LSD) test at a significance level of 0.05 (Gomez and Gomez, 1986).

\section{Results and Discussion}

\section{Phenology}

There was variation among the genotypes in relation to flowering. Table 1 showed that days required for first flowering of sesame genotypes varied from 26 to 32 days and $50 \%$ flowering from 43 to 51 days. The genotype Hathazari-4 flowered within 34 days while BD7001 took 41 days for flowering. Other genotypes such as BD-6992, BD-6995 and BD-7011 also took longer time for flowering. Four sesame genotypes required intermediate time for flowering ranging from 35 to 41 days. Among the genotypes the hathazari-4 flowered and matured earlier than other genotypes.

Table 1. Phenological events of five sesame genotypes

\begin{tabular}{l|cccc}
\hline Genotypes & \multicolumn{3}{|c}{ Days to } \\
\cline { 2 - 4 } & $\mathbf{1}^{\text {st }}$ flowering & 50\% flowering & Maturity \\
\hline BD-6992 & 32 & 41 & 85 \\
BD-6995 & 30 & 40 & 83 \\
BD-7001 & 31 & 41 & 83 \\
BD-7011 & 30 & 41 & 85 \\
Hathazari-4 & 26 & 34 & 76 \\
\hline LSD (0.05) & 0.64 & 0.64 & 1.14 \\
CV (\%) & 1.39 & 1.06 & 0.90 \\
\hline
\end{tabular}

\section{Morpho-physiological characters}

\section{Plant height}

The sesame genotypes differed significantly in height at all stages of their growth but not at initial stage. Irrespective of genotypes, the height of sesame plants increased rapidly at the early stages of growth and rate of progression in height was slow at the later stages (Table 2). The genotypes attained their peak height at maturity. Plant height ranged between 124.7 $\mathrm{cm}$ and $137.3 \mathrm{~cm}$. Hathazari-4 produced the tallest plants $(137.3 \mathrm{~cm})$ and BD-6992 the shortest $(124.7 \mathrm{~cm}$ ). All genotypes attained their peak height at 85 Days After Emergence (DAE) . Plant height is an important morphological character of crop that showed positive correlation with seed yield of sesame although it may be reversed in other circumstances (Rubio et al., 2004). 
Akter et al.

\section{Number of leaves per plant}

Table 2 shows the number of leaves in sesame genotypes throughout the crop duration. In sesame plant, the highest number of leaves per plant (35.3) was found in the genotype Hathazari-4. Number of leaves per plant increased during early growth stages of sesame and decreased later due to leaf senescence. Leaves play a major role in synthesis and translocation of photo-assimilates to the seeds and affect grain yield. A strong relationship exists between LAI and number of leaves per plant i.e. more number of leaves per plant ensures increased canopy cover and increased photosynthetic activity (Saipan et al. 2010).

Table 2. Variation in plant height and leaf number over time in five sesame genotypes

\begin{tabular}{l|ccc|c|c|cc}
\hline \multirow{2}{*}{ Genotypes } & \multicolumn{4}{|c|}{ Plant height (cm) } & \multicolumn{3}{c}{ Leaf number } \\
\cline { 2 - 8 } & 20DAE & 40DAE & 60DAE & 85DAE & 20 DAE & 40 DAE & 60 DAE \\
\hline BD-6992 & 32.47 & 101.20 & 123.00 & 124.70 & 8.65 & 26.70 & 18.35 \\
BD-6995 & 32.47 & 103.50 & 133.01 & 134.40 & 8.35 & 23.00 & 18.35 \\
BD-7001 & 33.88 & 102.10 & 129.20 & 130.60 & 8.80 & 27.90 & 21.35 \\
BD-7011 & 33.92 & 112.20 & 129.70 & 131.20 & 9.00 & 26.00 & 20.05 \\
Hathazari-4 & 33.17 & 114.60 & 136.30 & 137.30 & 10.55 & 35.30 & 25.95 \\
\hline LSD (0.05) & NS & 6 & 8 & 8 & 1.42 & 5.32 & 5.04 \\
CV (\%) & 7.69 & 4.66 & 4.47 & 4.44 & 10.13 & 12.43 & 14.90 \\
\hline
\end{tabular}

NS $=$ Non-significant

\section{Leaf area indices}

Table 3 shows the LAI of sesame genotypes throughout the crop duration. LAI increased progressively from early growth stages of sesame and attained peak at 40 DAE and then decreased gradually. The genotypes differed in LAl at all the sampling dates. Among the genotypes Hathazari-4 had the highest LAI in all sampling dates. Leaf area index is most important for interception of light and photosynthesis. The more LAI caused more photosynthesis and produced more dry matter. The initial increase of LAI in sesame is associated with the higher number of leaves per plant and higher photosynthetic leaf surface area. The decline in LAl after attaining the peak might be due to senescence of leaves from the base of the stem approaching upward. Leaf area index and activity per unit leaf area are components of field photosynthetic performance (De Costa and Shanmugathasan, 2002).

Table 3. Variation in leaf area and leaf area index over time in five sesame genotypes

\begin{tabular}{l|ccc|c|c|c}
\hline \multirow{2}{*}{ Genotypes } & \multicolumn{3}{|c|}{ Leaf area per plant $\left(\mathrm{cm}^{2}\right)$} & \multicolumn{3}{c}{ Leaf area index } \\
\cline { 2 - 7 } & $20 \mathrm{DAE}$ & $40 \mathrm{DAE}$ & $60 \mathrm{DAE}$ & 20DAE & 40DAE & $60 \mathrm{DAE}$ \\
\hline BD-6992 & 227.9 & 819.1 & 705.4 & 0.57 & 2.05 & 1.76 \\
BD-6995 & 239.7 & 845.1 & 715.3 & 0.59 & 2.12 & 1.79 \\
BD-7001 & 200.3 & 848.8 & 730.9 & 0.50 & 1.87 & 1.80 \\
BD-7011 & 205.3 & 746.9 & 719.4 & 0.51 & 2.12 & 1.83 \\
Hathazari-4 & 316.1 & 1246 & 889.1 & 0.79 & 3.11 & 2.22 \\
\hline LSD (0.05) & 67.50 & 210.1 & 56.47 & 0.17 & 0.53 & $\mathrm{NS}$ \\
CV (\%) & 18.42 & 15.23 & 15.36 & 18.36 & 15.26 & 0.53 \\
\hline
\end{tabular}

NS = Non-significant

Light interception

Interception of light at capsule initiation stage of sesame genotype is presented in Table 4. In Hathazari-4 the maximum amount of light was intercepted at capsule initiation stage. From the Table 4 it is revealed that light penetration through the canopy is genotype dependent. The genotypes BD-7001 transmitted more portion of radiation to ground level in comparison 
Photosynthesis, Dry Matter Partitioning and Yield Variation in Sesame Genotypes

to Hathazari-4 indicating that canopy of BD-7001 is less efficient in light interception. The genotype Hathazari-4 intercepted highest amount of light at capsule initiation stage which was $95.00 \%$. The more the LAl, greater was the light interception. The lowest light interception was $87.21 \%$ in the genotype BD-7001. This was attributed to lower LAI. The amount of light intercepted by a canopy is a function of LAI. Maximizing light interception during seed formation is required for maximum yield. Light capture is highly affected by canopy size, and the amount of PAR intercepted by crops along the season is commonly related to crop growth and grain yield (Singer, 2001).

Table 4. Variation in light interception at capsule initiation stage in sesame genotypes

\begin{tabular}{l|c}
\hline Genotypes & Light interception at capsule initiation stage (\%) \\
\hline BD-6992 & 93.02 \\
BD-6995 & 94.63 \\
BD-7001 & 87.21 \\
BD-7011 & 92.49 \\
Hathazari-4 & 95.00 \\
\hline LSD (0.05) & NS \\
CV (\%) & 3.94 \\
\hline
\end{tabular}

\section{Photosynthesis}

Growth, dry matter production and yield depend almost entirely on photosynthesis of crop plants. Photosynthesis depends on the leaf area development and the extent of light intercepted by the canopy. Variation in leaf photosynthesis was low at the capsule development stage in five sesame genotypes (Table 5). Higher leaf photosynthetic rate was recorded in the genotype Hathazari-4 $\left(28.87 \mu \mathrm{molm}^{-2} \mathrm{~s}^{-1}\right)$ but it was not significant compared to the sesame genotypes. The amount of photosynthate is a function of total leaf area and solar radiation intercepted by the crop canopies. Differences in photosynthetic rate among crop varieties are important for understanding the plant capacity to produce economic yield (Islam et al., 1994).

\section{Intercellular $\mathrm{CO}_{2}$ concentration}

There was no significant difference in intercellular $\mathrm{CO}_{2}$ concentration $(\mathrm{Ci})$ in sesame leaves due to genotypic variation and it ranged from 222.9 to $239.9 \mathrm{ppm}$ at capsule initiation stage (Table 5). The lowest intercellular $\mathrm{CO}_{2}(222.9 \mathrm{ppm})$ was observed in the genotype Hathazari-4 and the highest (239.9 ppm) in the genotype BD-7001. Higher intercellular $\mathrm{CO}_{2}$ concentration might have been due to slower photosynthetic rates of leaves (Hasan, 1993).

\section{Stomatal conductance}

Stomatal conductance was positively correlated to the photosynthetic rates of sesame. At capsule initiation stage, the highest stomatal conductance $\left(0.80 \mathrm{cms}^{-1}\right)$ was recorded from the genotype Hathazari-4. This apparently was due to faster rate of intercellular $\mathrm{CO}_{2}$ utilization compared to the rate of $\mathrm{CO}_{2}$ uptake through stomata in this genotype.

Table 5. Variation in photosynthetic rate, stomatal conductance and intercellular $\mathrm{CO}_{2}$ concentration at capsule initiation stage in five sesame genotypes

\begin{tabular}{l|c|c|c}
\hline Genotypes & $\begin{array}{c}\text { Photosynthetic rate } \\
\left(\mu \mathrm{molm} \mathrm{m}^{-1} \mathrm{~s}^{-1}\right)\end{array}$ & $\begin{array}{c}\text { Stomatal } \\
\text { conductance } \\
\left(\mathrm{cms}^{-1}\right)\end{array}$ & $\begin{array}{c}\text { Intercellular } \mathrm{CO}_{2} \\
\text { concentration }(\mathrm{ppm})\end{array}$ \\
\hline
\end{tabular}


Akter et al.

\begin{tabular}{lccc}
\hline BD-6992 & 27.98 & 0.59 & 238.3 \\
DB-6995 & 27.49 & 0.56 & 233.1 \\
DB-7001 & 27.40 & 0.54 & 239.9 \\
BD-7011 & 27.09 & 0.62 & 234.1 \\
Hathazari-4 & 28.87 & 0.80 & 222.9 \\
\hline LSD $(0.05)$ & $\mathrm{NS}$ & $\mathrm{NS}$ & $\mathrm{NS}$ \\
CV $(\%)$ & 6.28 & 0.25 & 5.36 \\
\hline
\end{tabular}

NS = Non-significant

\section{SPAD value}

The SPAD value is closely correlated with leaf chlorophyll content. Chlorophyll is a basic component for photosynthesis. Higher the leaf chlorophyll content, faster is the photosynthesis. At early stage of plant leaf chlorophyll concentration was lower. With the advancement of crop growth, chlorophyll content of leaf increased at a parabolic shape reaching peak at around 50DAE and then declined. The highest SPAD value (48.15) was obtained at 40 DAE in the genotype BD-6995 and lowest (42.95) in the genotype BD-7011 (Table 6). The variation observed in SPAD value among the genotypes might be due to difference in genetic constituents and environmental effect. Reduction in SPAD value in later stage due to maturity of leaves and leaf senescence has already occurred in reproductive stage.

Table 6. Variation in SPAD value over time in five selected sesame genotypes

\begin{tabular}{l|c|c|c|c|c}
\hline \multirow{2}{*}{ Genotypes } & \multicolumn{5}{|c}{ SPAD } \\
\cline { 2 - 6 } & 20DAE & 30DAE & 40DAE & 50DAE & 60DAE \\
\hline BD-6992 & 36.20 & 42.15 & 45.28 & 41.08 & 35.70 \\
BD-6995 & 34.45 & 43.50 & 48.15 & 43.08 & 34.95 \\
BD-7001 & 37.25 & 41.88 & 46.65 & 43.03 & 35.45 \\
BD-7011 & 33.72 & 41.50 & 42.95 & 40.20 & 34.22 \\
Hathazari-4 & 41.95 & 45.28 & 47.6 & 43.70 & 39.00 \\
\hline LSD (0.05) & 3.45 & 3.22 & 4.80 & 4.48 & 3.50 \\
CV (\%) & 6.10 & 4.87 & 6.75 & 6.89 & 6.28 \\
\hline
\end{tabular}

\section{Dry matter partitioning}

\section{Leaf dry weight}

Dry matter partitioning into leaf increased linearly up to a certain period and then gradually decreased regardless of genotypes (Figure 1). Regardless of genotypes, the accumulation of dry matter in leaf increased over time reaching a peak at around 60 DAE in sesame genotypes. At the attainment of peaks, leaf dry weights were $4.73 \mathrm{~g} \mathrm{plant}^{-1}$ (BD-6992), $4.12 \mathrm{~g}$ plant $^{-1}$ (BD-6995), 4.31 gplant ${ }^{-1}$ (BD-7001), 4.78g plant $^{-1}(7011)$ and $6.15 \mathrm{~g} \mathrm{plant}^{-1}$ (Hathazari- $^{-}$ 4 ) in sesame genotypes, respectively. The maximum leaf dry weight was recorded in the genotype Hathazari-4 (6.15g plant $\left.{ }^{-1}\right)$. The genotypes showed significant differences in dry matter accumulation in leaf in all sampling periods. The leaf dry weight decreased after the attainment of the peak in all the genotypes. This decrease in leaf dry weight might be due to translocation of assimilates from leaves to reproductive organs. Leaf dry weight increased with increase in leaf size and chlorophyll content, delayed maturity time and increased vegetative growth period as stated by (Haruna et al., 2011). 
Photosynthesis, Dry Matter Partitioning and Yield Variation in Sesame Genotypes

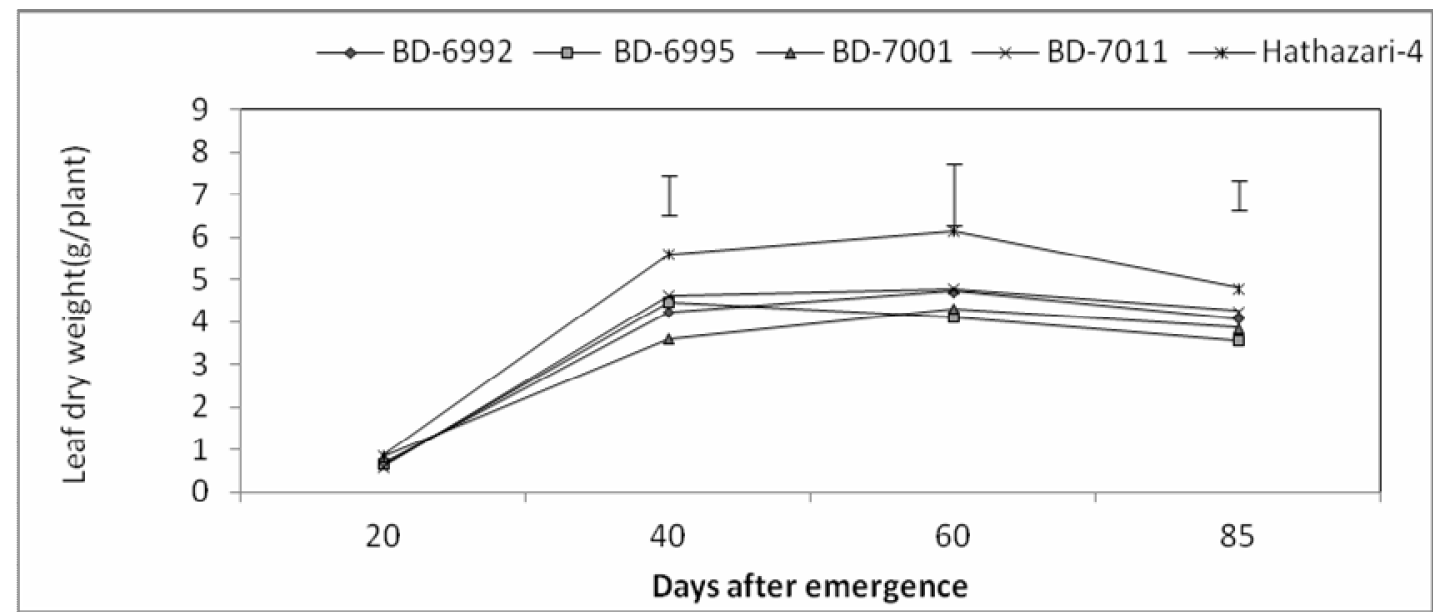

Fig. 1. Vatiation in leaf dry matter accumulation over time in sesame genotypes. Vertical bars indicate LSD (0.05).

\section{Stem dry matter}

Dry matter accumulation in stem as a result of stem elongation and stored photosynthates showed a significant variation in sesame genotypes over time as shown in Figure 2 . The stem dry weight increased slowly up to 20DAE and continued to increase till maturity. The highest stem dry weight was obtained at 60 DAE which was $9 \mathrm{~g} \mathrm{plant}^{-1}, 9.6 \mathrm{~g} \mathrm{plant}^{-1}, 9.1 \mathrm{~g}$

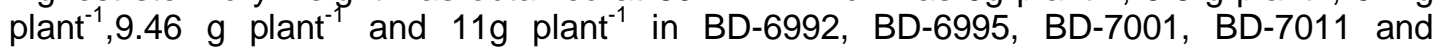
Hathazari-4, respectively. The dry weight of stem declined after the attainment of the peak in all the genotypes. There was slight decrease in stem dry weight at final harvest. This might be due to continuous supply of current assimilates for the development of grains.

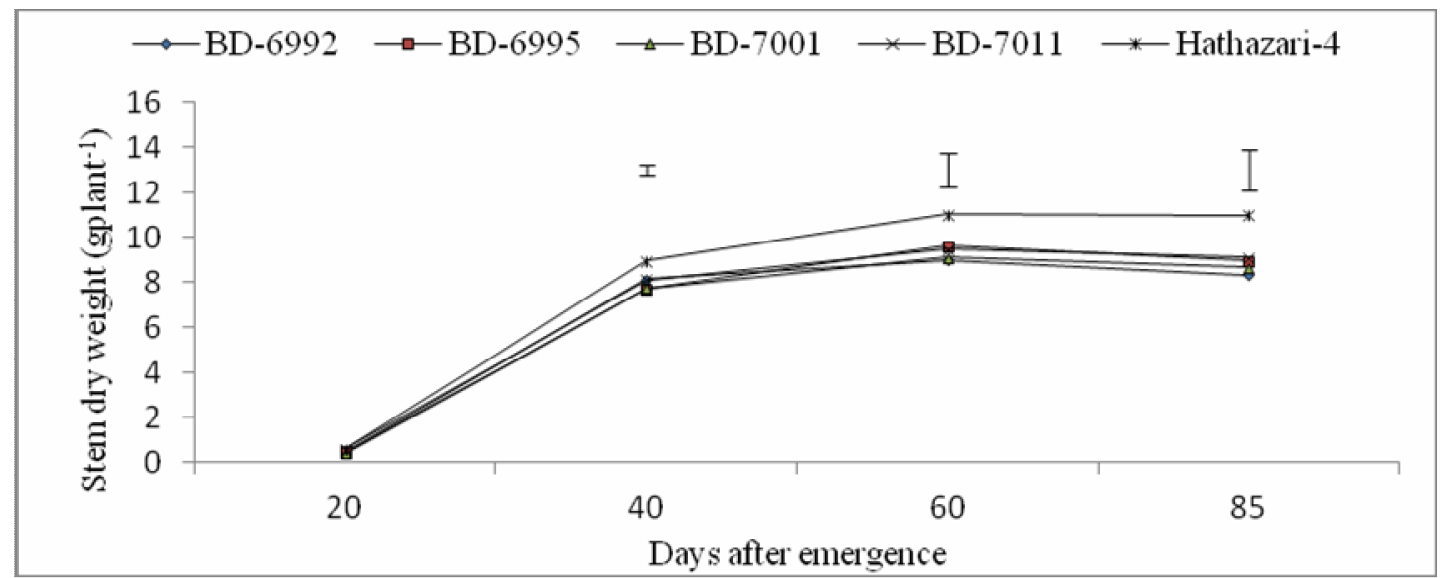

Fig. 2. Variation in stem dry matter accumulation over time in sesame genotypes.

\section{Capsule dry matter} Vertical bars indicate LSD (0.05).

Figure 3 shows that the accumulation of dry matter in capsule was less at the beginning and it increased rapidly later on. Dry matter accumulation in capsule started earlier in hathazari4. Capsule dry weight continued to increase till maturity. The genotypes showed significant differences in capsule dry weight in 40 DAE and 85 DAE. Capsule dry weight ranged from 
Akter et al.

$9.7 \mathrm{~g} \mathrm{plant}^{-1}$ (Hathazari-4) to $6.98 \mathrm{~g} \mathrm{plant}^{-1}$ (BD-7011). The highest contribution to total dry weight per plant was made by capsule dry weight per plant. The highest contribution of capsule to the total dry weight could be attributed to the fact that at flowering, most of the assimilation was partitioned to the sink (capsule). This continued until physiological maturity is attained. (Haruna et al., 2011).

Fig. 3. Variation in capsule dry matter accumulation over time in sesame genotypes. Vertical bars indicate LSD (0.05).

\section{Yield components of sesame}

\section{Number of capsules per plant}

There was significant variation in the number of capsules per plant in sesame genotypes (Table 7). The highest number of capsules plant ${ }^{-1}(63.65)$ was obtained in the genotypes Hathazari-4 and the lowest number of capsules plant ${ }^{-1}$ (38.40) in genotypes BD-7001.

\section{Number of seeds per capsule}

The highest number of seeds capsule $e^{-1}(77)$ was obtained in genotype Hathazari-4. The lowest number of seeds capsule ${ }^{-1}$ (59.83) was obtained in genotype BD-7001which was statistically different. Delay in harvesting reduced the number of seeds capsule ${ }^{-1}$ (Mondal et al., 2004).

\section{Thousand seed weight}

The 1000-grain weight did not vary significantly in the genotypes (Table 7). The 1000-grain weight varied from $2.93 \mathrm{~g}$ to $3.40 \mathrm{~g}$. The highest 1000 -grain weight $(3.40 \mathrm{~g})$ was recorded in the genotype-BD 6992 and the lowest $(2.93 \mathrm{~g})$ in the genotype-BD 7011 . The direct effects of 1000-seed weight on seed yield were low and positive. (Yadava et al., 1983).

\section{Seed yield}

Seed yield of five sesame genotypes ranged from 1.83 to $3.52 \mathrm{t} \mathrm{ha}^{-1}$ (Table 7). The highest seed yield (3.52 $\left.\mathrm{t} \mathrm{ha}^{-1}\right)$ was found in the genotype, Hathazari-4 and the lowest $\left(1.82 \mathrm{t} \mathrm{ha} \mathrm{H}^{-1}\right)$ in the genotypes BD-6992 and BD-7001.

\section{Oil content in seed}


Photosynthesis, Dry Matter Partitioning and Yield Variation in Sesame Genotypes

Genotypic variation in seed oil content of sesame is shown in Table 7. Percentage of oil in seeds varied slightly among the genotypes. The seed oil contents were $41.39 \%$ in the genotype BD-6992, 39.73\% in BD-6995, 40.26\% in BD-7001, 41.2\% in BD-7011 and $39.72 \%$ in the genotype Hathazari-4. The highest oil yield was obtained from the genotype Hathazari-4 (151.99 tha $\left.{ }^{-1}\right)$ and the lowest (73.27 tha $^{-1}$ ) from BD-7000.

Table 7. Yield component and seed yield, oil content in seeds and oil yield in five selected sesame genotypes

\begin{tabular}{|c|c|c|c|c|c|c|}
\hline Genotypes & $\begin{array}{l}\text { Capsules } \\
\text { plant }^{-1}\end{array}$ & $\begin{array}{c}\text { Seed } \\
\text { capsule }^{-1}\end{array}$ & $\begin{array}{l}\text { 1000-seed } \\
\text { Weight }(\mathrm{g})\end{array}$ & $\begin{array}{l}\text { Seed yield } \\
\left.\text { (tha }^{-1}\right)\end{array}$ & $\begin{array}{c}\text { Seed oil } \\
\text { content (\%) }\end{array}$ & $\begin{array}{c}\text { Seed oil } \\
\text { yield }\left(\text { tha }^{-1}\right)\end{array}$ \\
\hline BD-6992 & 47.1 & 67.15 & 3.40 & 1.83 & 41.39 & 0.753 \\
\hline BD-6995 & 44.08 & 67.63 & 2.94 & 2.02 & 39.73 & 0.803 \\
\hline BD-7001 & 38.4 & 59.83 & 3.30 & 1.82 & 40.26 & 0.733 \\
\hline BD-7011 & 45.78 & 70.07 & 2.94 & 2.51 & 41.20 & 1.04 \\
\hline Hathazari-4 & 63.65 & 77.00 & 3.38 & 3.52 & 39.72 & 1.53 \\
\hline LSD (0.05) & 5.00 & 9.53 & NS & 0.48 & 0.62 & 0.29 \\
\hline $\mathrm{CV}(\%)$ & 6.80 & 8.89 & 5.44 & 13.37 & .99 & 13.23 \\
\hline
\end{tabular}

NS $=$ Non-significant

\section{Conclusion}

Genotypic variability in terms of photosynthetic rate, dry matter partitioning, seed and oil yield was found in five sesame genotypes. Based on the present study it could be concluded that sesame genotype Hathazari-4 showed the best performance in terms of photosynthetic rate, dry matter partitioning, seed yield and oil yield.

\section{References}

Banglapedia. 2012. Available from: www.banglapedia.org/HT/S_0249.htm

BARC (Bangladesh Agricultural Research Council). 2012. Fertilizer Recommendation Guide2012. Farmgate, New Airport Road, Dhaka 1215. Pp. 106.

BBS (Bangladesh Bureau of statistics). 2012. Statistical year book of Bangladesh. 2012. Bangladesh Bureau of Statistics, Statics Division, Ministry of planning, Government of People's Republic of Bangladesh, Dhaka. Pp. 91.

Caliscan, S., M. Arstan, H. Atiogle and N. Isler. 2004. Effect of Planting Method and Plant Population on Growth and Yield of Sesame (Sesamum indicum L) in a Mediterranean type of Environment. Asia J. Plant Sci. 3(5): 610-613.

Carlsson, A. S., N. P. Chanana, S. Gudu, M. C. Suh and B. A. Were. 2008. Sesame. In: C. Kole and T. C. Hall (eds.). Compendium of transgenic crop plant- Transgenic oilseed crops. Wiley-Blackwell. Pp. 227-246.

De Costa and K. N. Shanmugathasan. 2002. Physiology of yield determination of soybean (Glycine max L.) under different irrigation regimes in the sub-humid zone of Sri Lanka. Field Crops Res. 75: 23-35.

Gomez K. A. and A. A. Gomez. 1986. Statistical Procedures for Agricultural Research. John Wiley and Sons, New York, USA. Pp. 680. 
Akter et al.

Haruna, I. M., S. M. Maunde and S. Yahuza. 2011. Growth and calyx yield of roselle (Hibiscus sabdariffa L.) as affected by poultry manure and nitrogen fertilizer rates in the southern guinea savanna of Nigeria. Can. J. Pure Appl. Sci. 5(1): 1345-1348.

Hasan, M. S. 1993. Genotypic variation in yield of blackgram (Vigna mungo L. Hepper) in relation to morphological and physiological characters. An unpublished M.S. thesis, submitted to the Dept. of Agronomy, IPSA,Gazipur-1703.

Islam, M. T. 1994. Ecophysiological studies on photosynthesis and dry matter production in mungbean. Ph.D. Dissertation, Kyushu University, Fukuoka, Japan.

Mondal, M. M. A., R. K. Dutta and M. A. Islam. 2004. Yield performance of some elite mungbean mutant in the northern region of Bangladesh. Bangladesh J. Nuclear Arric. 19: 32-35.

Ojima, M., R. Kawashima and K. Mikoshiba. 1969. Studies on the seed production of soybean. VII. The ability of photosynthesis in F1 and F2 generations. Crop Sci. Soc. Japan Proc. 38: 693.

Pham, D. T., T. T. D. Nguyen, A. S. Carlsson and M. T. Bui. 2010. Morphological evaluation of sesame (Sesamum indicum L.) varieties from different origins. Aust. J. Crop Sci. 4(7): 498-504.

Rubio, J., J. I. Cubero, L. M. Martin, M. J. Suso and F. Flores. 2004. Biplot analysis of trait relation of white lupin in Spain. Euphytica 135: 217-224.

Sanipan, C., K. D. Animesh, S. Aditi, S. Sonali, P. Rita, M. Susmita and D. Ananya. 2010. Traits influencing yield in sesame (Sesamum indicum L.) and Multilocational trials of yield parameters in some desirable plant types. Indian J. Sci. Technol. 3: 163-166.

Singer, J. W. 2001. Soybean light interception and yield response to row spacing and biomass removal. Crop Sci. 41: 424-429.

Vaughan, J. G. 2000. The structure and utilization of oil seed, $1^{\text {st }}$ Ed. Chapman and Hall Ltd., London. Pp. 201.

Yadava, T. P., P. Kumar and A. K. Yadava. 1983. Association of yield with some quality attributes in Indian mustard. Indian J. Agric. Sci. 53: 685-686. 